\title{
GENERAL SURGEONS; WORK LOAD \& MANAGEMENT PATTERN IN MEDICAL TEACHING INSTITUTION LADY READING HOSPITAL PESHAWAR. hamzakmc@gmail.com
}

1. Senior Registrar,

Surgical Department of Medical teaching

Institution Lady Reading Hospital Peshawar.

2. Assistant Professor Hematology, Nowshera Medical College, Nowshera

Correspondence Address: Dr. Abdul Qayyum

Senior Registrar, Surgical D Unit, Medical Teaching Institute, Lady Reading Hospital, Peshawar. hamzakmc@gmail.com

Article received on: 06/04/2016 Accepted for publication: 10/06/2016

Received after proof reading: 08/08/2016

\section{Dr. Abdul Qayyum', Dr. Hamzullah Khan²}

ABSTRACT... Objectives: The objectives of this study were to find out the frequency of surgical cases and types of surgical interventions in a tertiary care hospital of Peshawar. Study Design: Descriptive observational study Period: Jan to June 2015. Setting: Surgical "D" Unit of Medical Teaching institution, Lady Reading Hospital Peshawar. Material and methods: Relevant information's were recorded on a pre-designed proforma prepared in accordance with the objectives of the study. Results: A total of 842 patients who were admitted in the MTILRH Surgical D Unit were enrolled in the study irrespective of age, gender and geographical representation. Out of total $58 \%$ were males and $42 \%$ females. The age range of patient was from 2 years to 92 years the maximum. The mean of age with SD was 30 years \pm 3.5 SD. Mode of age was 27 years. The frequency of surgical cases presentation (via emergency or outdoor department) were; Acute appendicitis $26 \%$, cholilithiasis $17 \%$, acute abdomen $9.2 \%$, fire arm injuries/medico-legal cases 3.3\%, peri-anal problems (pilonodal sinuses, hemorrhoids, fistula, anal fissure) $8.8 \%$, Hernia (RIH\& LIH 13\%), carcinoma cases (stomach, rectum, pancreas) $1.5 \%$, diabetic foot $3 \%$, intestinal perforation \& ileostomy $2.8 \%$, etc. The frequency of types of surgical procedures were; The frequency of types of surgical procedures were; Open appendicectomy $25 \%$, Exploration laprotomy $8.4 \%$, debridement $2 \%$, Peri anal surgeries (EUA, Haemorridictomy, anal dilatation, fistulectomy $9.4 \%$ ), hernirraphy and hernitomy $16 \%$, open cholecystectomy $13 \%$, laproscopic cholecystectomy $4.4 \%$, orchiodectomy \& orchidopexy $5 \%$, and colostomy reversal $2.2 \%$ etc. $2 \%$ patients managed conservatively. Eight patients expired during the treatment (1\%). $97 \%$ discharged satisfactorily. There were 2 medico-legal cases that after discharged went in law in forces custody. Conclusion: The commonest cause of seeking surgical care was acute abdomen, FAI/MLC, cholilithiases, perianal disorders, hernia and testicular/scrotal problem are major surgical emergencies that we receive in our unit. In response the major types of surgical interventions are appendicectomy, Exploration laprotomy, open cholecystectomy, laproscopic cholecystectomy, hernirraphy and hernitomy, orchiodectomy \&orchidopexy and colostomies. There is $1 \%$ moratlity rate as observed.

Key word: $\quad$ Surgical emergencies, Types of surgical interventions, descriptive analysis

Article Citation: Qayyum A, Khan H. General surgeons; work load \& management pattern in medical teaching institution lady reading hospital Peshawar. Professional Med J 2016;23(8):959-963. DOI: 10.17957/TPMJ/16.3393

\section{INTRODUCTION}

General surgery considered to be the major specialty that deal with high volumes of emergency admissions in hospital. Emergency surgical management is of high priority in teaching hospitals and it is a very important for training surgical residents. There is a timely increase in the number of emergency admissions to hospital which include number of surgical emergencies. ${ }^{1}$ A study reported that the majority of patients had intestinal problems $(29.1 \%)$, urinary tract diseases $(21.4 \%)$, hernia (15.6\%), superficial lumps (12\%), hepato-biliary-pancreatic diseases
$(9.1 \%)$, breast diseases $(4.2 \%)$, scrotal diseases (3.3\%) and thyroid diseases (1.7). A total of 726 (64.5\%) patients were managed as elective cases, while 399 (35.5\%) were managed as emergency cases. $^{2}$ The spectrum of apparent emergencies received with procedures is generally considered a reflection of disease prevalence in a region. In a reportpublished by the AmericanBoard of Surgery, the average number of surgical procedures performed by general/laproscopic surgeons were: abdomenal (hepato-biliary-pancreatic + hernia) $26 \%$, alimentary tract/obstruction $16 \%$, breast surgeries $14 \%$, endoscopic $13 \%$, skin/soft 
tissue debridement $12 \%$ and vascular procedures in $10 \% .^{3}$

Medical Teaching Institution, Lady Reading Hospital Peshawar is 1600 beds tertiary care hospital. It has four surgical units. These facts and figures represent only Surgical D Unit of the hospital. MTI-LRH is the main hospital that receives all types of emergencies including natural or disastrous or bomb blast etc.

This study was performed to see the pattern of surgical emergencies and their management in a tertiary care hospital of Peshawar.

\section{MATERIAL AND METHODS}

This descriptive observational study was conducted in Medical Teaching Institution, Lady Reading Hospital Peshawar, from January 2015 to June 2015. A total of 872 patients who were admitted in the MTI-LRH Surgical D Unit were enrolled in the study irrespective of age, gender and geographical representation. Out of total $58 \%$ were males and $42 \%$ females.

Exclusion criteria were patients admitted in other units of the surgical department of the hospital as well as patients admitted in other surgical and allied units. Inclusion criteria were all patients were admitted through out-patient department (OPD) or from emergency department or shifted directly to surgery from other departments.

The variables recorded and analyzed were patient's demographic information's, final diagnosis, disease pattern, presentation complaints, reason of admission, mode of treatment, type of operation, complications and the final outcome at time of discharge. Cases that left unit against medical advice (LAMA) were excluded.

Name, age, gender, address were the geographical variables, while the outcome, procedures and reason for admission (surgical emergencies were data variables. relevant information's were collected on a predesigned questionnaire prepared in accordance with the objectives of the study.

Data was entered in Ms-Excel 2010 and analyzed for percentages and mean.

\section{RESULTS}

A total of 872 patients who were admitted in the MTI-LRH Surgical D Unit were enrolled in the study irrespective of age, gender and geographical representation. Out of total $58 \%$ were males and $42 \%$ females (Table-I).

The age range of patient was from 2 years to 92 years the maximum. The mean of age with SD was 30 years $\pm 3.5 \mathrm{SD}$. Mode of age was 27 years. 15 patients were in pediatric age group that were operated (table-II).

The frequency of surgical cases presentation (via emergency or outdoor department) were; Acute appendicitis $26 \%$, cholilithiasis $17 \%$, acute abdomen $9.2 \%$, fire arm injuries/medicolegal cases $3.3 \%$, peri-anal problems (pilonodal sinuses, hemorrhoids, fistula, anal fissure) 8.8\%, Hernia (RIH\& LIH 13\%), carcinoma cases (stomach, rectum, pancreas) $1.5 \%$, diabetic foot $3 \%$, intestinal perforation \& ileostomy $2.8 \%$, etc(Table-III).

The frequency of types of surgical procedures were; Open appendicectomy 25\%, Exploration laprotomy $8.4 \%$, debridement $2 \%$, peri anal surgeries (EUA, Haemorridictomy, anal dilatation, fistulectomy 9.4\%), hernirraphy and hernitomy $16 \%$, open cholecystectomy $13 \%$, laproscopic cholecystectomy 4.4\%, orchiodectomy \& orchidopexy $5 \%$, and colostomy reversal $2.2 \%$ etc. (Table-IV).

Eight patients expired during the treatment (1\%). $97 \%$ discharged satisfactorily. There were 2 medico legal cases that after discharged went in law in forces custody. (Table-V).

\begin{tabular}{|l|c|c|}
\hline \multicolumn{1}{|c|}{ Sex } & Total & percentage \\
\hline Females & 353 & 41.92 \\
\hline Males & 489 & 58.08 \\
\hline Grand Total & 842 & \\
\hline
\end{tabular}

Table-I. Gender wise distribution of patients. 


\begin{tabular}{|l|c|c|}
\hline \multicolumn{1}{|c|}{ Age } & Total & percentage \\
\hline $2-11$ & 11 & 1.31 \\
\hline $12-21$ & 193 & 22.92 \\
\hline $22-31$ & 242 & 28.74 \\
\hline $32-41$ & 148 & 17.58 \\
\hline $42-51$ & 115 & 13.66 \\
\hline $52-61$ & 80 & 9.50 \\
\hline $62-71$ & 46 & 5.46 \\
\hline $72-81$ & 6 & 0.71 \\
\hline $82-92$ & 1 & 0.12 \\
\hline Grand Total & 842 & \\
\hline Table-lI. Age based categorization of patints \\
\hline
\end{tabular}

\begin{tabular}{|l|c|c|}
\hline Outdoor admission complain list & & \\
\hline Final Diagnosis & Total & percentage \\
\hline Abscess & 7 & 0.83 \\
\hline $\begin{array}{l}\text { Peri-anal problems (Anal Fissure, } \\
\text { bleeding P/R, Fistula in ano, } \\
\text { Pilonodal sinus) }\end{array}$ & 68 & 8.08 \\
\hline Bed sore+ infected wound & 12 & 1.423 \\
\hline Bleeding PV & 2 & 0.24 \\
\hline Benign prostatic hyperplasia & 3 & 0.36 \\
\hline Ca Head of Pancrease & 4 & 0.48 \\
\hline Carcinoma (Rectum+stomach) & 6 & 0.71 \\
\hline Cholelithiasis & 144 & 17.10 \\
\hline Diabetic Foot & 26 & 3.09 \\
\hline Dj Stent & 5 & 0.59 \\
\hline Epigastric Hernia & 13 & 1.54 \\
\hline Fibroid Uterus & 7 & 0.83 \\
\hline Inguinal Hernia (left or right) & 111 & 13.18 \\
\hline lleostomy +colostomy & 24 & 2.85 \\
\hline Lipoma & 4 & 0.48 \\
\hline Liver Mass & 3 & 0.36 \\
\hline Mass Abdomen & 1 & 0.12 \\
\hline Scrotal swelling (Vericolcel & 43 & 5.11 \\
\hline +Hydrocel) & & \\
\hline Thyroid swelling & 2 & 0.24 \\
\hline Emergency admissions & & \\
\hline Acute Abdomen & 77 & 9.15 \\
\hline Pain RIF & 219 & 26.01 \\
\hline Acute Pancreatitis & 11 & 1.31 \\
\hline Duadenal Perforation & 1 & 0.12 \\
\hline FAl / MLC & 28 & 3.33 \\
\hline Intestinal perforation & 5 & 0.59 \\
\hline Psoas Abscess & 1 & 0.12 \\
\hline Stab Wound & 7 & 0.83 \\
\hline Urinary Retention & 7 & 0.83 \\
\hline Psoas Abscess & 842 & 0.12 \\
\hline Grand total & & \\
\hline Table-III. Patient presentation complaints & statistics. \\
\hline & & \\
\hline
\end{tabular}

\begin{tabular}{|l|c|c|}
\hline Elective procedures list & Total & percentage \\
\hline Procedure Name (if done) & 9 & 1.07 \\
\hline DJ Stent Removal & 2 & 0.24 \\
\hline Aspiration & 16 & 1.90 \\
\hline Conservatively Managed & 38 & 4.51 \\
\hline Dressing and Debridement & 5 & 0.59 \\
\hline Darning Repair & 5 & 0.59 \\
\hline Excision of Lipoma & 82 & 9.74 \\
\hline $\begin{array}{l}\text { Peri-anal surgeries(EUA } \\
\text { +Haemorridictomy, dilatation, } \\
\text { fistulectomy) }\end{array}$ & 7 & 0.83 \\
\hline Incision and drainage & 17 & 2.02 \\
\hline $\begin{array}{l}\text { ileostomy/Colostomy/Colostomy } \\
\text { Reversal }\end{array}$ & 37 & 4.39 \\
\hline Lap Cholecystectomy & 1 & 0.12 \\
\hline Ligation Lt Varicocele & 42 & 4.99 \\
\hline $\begin{array}{l}\text { Left and right Orchidectomy/ } \\
\text { orchidopexy }\end{array}$ & 135 & 16.03 \\
\hline Mesh Repair and herniotomy & 109 & 12.95 \\
\hline Open Cholecystectomy & 1 & 0.12 \\
\hline Redical Nephrectomy & 3 & 0.36 \\
\hline Sigmoidoscopy \& Biopsy & 7 & 0.83 \\
\hline Total abdominal Hystrectomy & 2 & 0.24 \\
\hline Thyroidectomy & 6 & 0.71 \\
\hline Trans-Vesical Prostectomy & 3 & 0.36 \\
\hline Whipple Procedure & 7 & 0.83 \\
\hline Emergency procedures list & 16 & 25.18 \\
\hline Acute Pancreatitis & 3 & 0.48 \\
\hline Appendicectomy & 2 & 8.43 \\
\hline Re- Exploration Laprotomy & 0.36 \\
\hline Cystoscopy & & 0.24 \\
\hline Exp Laprotomy & & \\
\hline Rouxen Gastrojetunostomy & & \\
\hline Urethral Dilation & & \\
\hline Grand total & & \\
\hline & & \\
\hline
\end{tabular}

Table-IV. Types of surgical interventions.

\begin{tabular}{|l|c|c|}
\hline \multicolumn{1}{|c|}{ Outcome of patients } & Total & Percentage \\
\hline Expired & 8 & 0.95 \\
\hline Medico-legal cases & 2 & 0.24 \\
\hline Satisfactory & 832 & 98.8 \\
\hline Grand Total & 842 & \\
\hline \multicolumn{2}{|c|}{ Table-V. Outcome data. } \\
\hline
\end{tabular}

\section{DISCUSSION}

The spectrum of procedure or pattern of admission in our unit also reflects the prevalence of the specific disease in our society as MTI-LRH receives patients for all over the province. 
The frequency of surgical cases presentation (via emergency or outdoor department) were; Acute appendicitis $26 \%$, cholilithiasis $17 \%$, acute abdomen $9.2 \%$, fire arm injuries/medicolegal cases $3.3 \%$, peri-anal problems (pilonodal sinuses, hemorrhoids, fistula, anal fissure) 8.8\%, Hernia (RIH\& LIH 13\%), carcinoma cases (stomach, rectum, pancreas) $1.5 \%$, diabetic foot $3 \%$, intestinal perforation \& ileostomy $2.8 \%$, etc. A matching study from Pakistan also reported acute appendicitis (22.4\%). ${ }^{2}$

Caterino from Rome reported appendicitis as the most frequent diagnosis (16.4\%), followed by nonspecific abdominal pain (15.5\%), cholelithiasis $(12.5 \%)$ and cancer of Gl tract (10.3\%). ${ }^{4}$

The next most common disease requiring a surgical procedure were peri-anal disorders $8.8 \%$, hemmorrhoids were major contributor to this group up to $6 \%$. The high prevalence is due to dietary pattern lacking fibers that causing constipation and forceful defecation, multiple pregnancies or occupation with prolonged standing. The prevalence rate of symptomatic haemorrhoids in the United States is $4.4 \%$ of the total adult population. ${ }^{5}$ which matches with our findings.

The frequency of types of surgical procedures were; The frequency of types of surgical procedures were; Open appendicectomy 25\%, Exploration laprotomy $8.4 \%$, debridement $2 \%$, peri anal surgeries (EUA, Haemorridictomy, anal dilatation, fistulectomy 9.4\%), hernirraphy and hernitomy 16\%, open cholecystectomy $13 \%$, laproscopic cholecystectomy $4.4 \%$, orchiodectomy \& orchidopexy $5 \%$, and colostomy reversal $2.2 \%$ etc.

Chianakwana et al did a study in Nigeria reported appendicectomy as the most common emergency operation in 139 patients, it is followed by road traffic accidents (RTAs) in 137 patients, fire arm injuries 127 cases, acute intestinal obstruction in 92 cases, acute urinary retention in 126 cases and priapism reported in 2 cases. $^{6}$ Acute appendicitis is among the most common causes of surgical abdominal diseases worldwide. ${ }^{7}$ Inguinal hernia $16 \%$ (is $2^{\text {nd }}$ most common surgical disease in this series, which also reported in several other international studies. ${ }^{8}$ Humber \& Frecker ${ }^{9}$ from rural areas of British Columbia reported appendicectomy and hernia surgery as the most common emergency and elective surgery operations respectively. Cholecystectomy in our study was $13 \%$ other study reported it 3.5\% and above. ${ }^{10}$ We had performed $9.4 \%$ peri-anal surgeries including major of these as haemorrhoidectomy (6.4\%). Another study also matching our findings as haemorrhoid or perianal surgery (4\%). ${ }^{11}$ There is $1 \%$ mortality rate as observed. Another study from Pakistan reported The mortality rate in their series was $0.62 \%{ }^{2}$

\section{CONCLUSION}

The commonest cause of seeking surgical care was acute abdomen, FAI/MLC, cholilithiases, perianal disorders, hernia and testicular/scrotal problem are major surgical emergencies that we receive in our unit. In response the major types of surgical interventions are appendicectomy, Exploration laprotomy, open cholecystectomy, laproscopic cholecystectomy, hernirraphy and hernitomy, orchiodectomy \& orchidopexy and colostomies. There is $1 \%$ moratlity rate as observed.

Copyright (C) 10 June, 2016.

\section{REFERENCES}

1. Campbell WB, Lee EJ, Van de Sijpe K, Gooding J, Cooper MJ. A 25-year study of emergency surgical admissions. Ann R Coll Surg Engl. 2002; 84:273-7.

2. Shamim M, Bano S, Iqbal SA Pattern of cases and its management in a general surgery unit of a rural teaching institution. JPMA 62: 148; 2012.

3. Ritchie WP Jr, Rhodes RS, Biester TW. Workloads and practice patterns of general surgeons in the United States, 1995-1997: a report from the American Board of Surgery. Ann Surg 1999; 230: 533-42.

4. Caterino S, Cavallini M, Meli C, Murante G, Schiffino $L$, Lotito $S$, Toncher $F$. Acute abdominal pain in emergency surgery: clinical epidemiologic study of 450 patients. Ann Ital Chir 1997; 68: 807-17.

5. Schubert MC, Sridhar S, Schade RR, Wexner SD. 
What every gastroenterologist needs to know about common anorectal disorders. World J Gastroenterol 2009; 15: 3201-9.

6. Chianakwana GU, Ihegihu CC, Okafor PI, Anyanwu $\mathrm{SN}$, Mbonu OO. Adult surgical emergencies in a developing country: the experience of Nnamdi Azikiwe University Teaching Hospital, Nnewi, Anambra State, Nigeria. World J Surg 2005; 29: 804-7.

7. Noudeh YJ, Sadigh N, Ahmadnia AY. Epidemiologic features, seasonal variations and false positive rate of acute appendicitis in Shahr-e-Rey, Tehran. Int J Surg 2007; 5: 95-8.
8. Campbell WB, Lee EJ, Van de Sijpe K, Gooding J, Cooper MJ. A 25-year study of emergency surgical admissions. Ann R Coll Surg Engl. 2002; 84:273-7.

9. Humber N, Frecker T. Rural surgery in British Columbia: is there anybody out there? Can J Surg 2008; 51: 179-84.

10. Ohene-Yeboah $\mathbf{M}$ Acute surgical admissions for abdominal pain in adults in Kumasi, Ghana. ANZ J Surg 2006; 76: 898-903.

11. Schirmer BD, Winters KL, Edlich RF. Cholelithiasis and cholecystitis. J Long Term Eff Med Implants 2005; 15: 329-38.

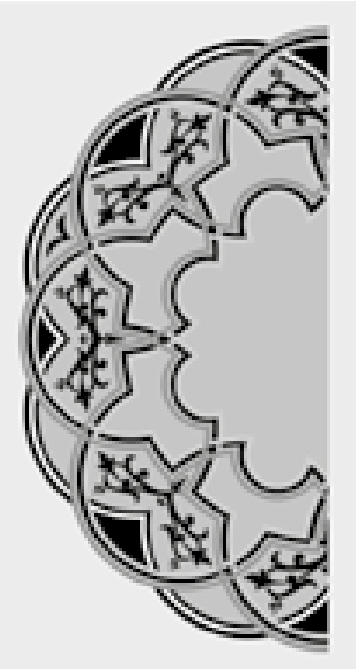

\title{
"Accepting responsibility is getting power."
}

\author{
Shuja Tahir
}

\section{AUTHORSHIP AND CONTRIBUTION DECLARATION}

\begin{tabular}{|c|c|c|c|}
\hline Sr. \# & Author-s Full Name & Contribution to the paper & Author $=\mathbf{s}$ Signature \\
\hline $\begin{array}{l}1 \\
2\end{array}$ & $\begin{array}{l}\text { Dr. Abdul Qayyum } \\
\text { Dr. Hamzullah Khan }\end{array}$ & $\begin{array}{l}\text { Paper writing, editing, } \\
\text { data collection } \\
\text { Paper writing, editing, } \\
\text { data collection }\end{array}$ & \\
\hline
\end{tabular}

